S. Alizada, $P h D$ in Economics, Senior Lecturer, Azerbaijan University of Architecture and Construction, Baku, Azerbaijan

ORCID ID: 0000-0001-8079-3255

\title{
CONCEPTUAL APPROACH TO REGULATION OF INVESTMENT POLICY IN CONSTRUCTION COMPANIES
}

\author{
W. I. Алізаде, \\ доктор філософії з економіки, старший викАадач, \\ Азербайджанський Архітектурно-Будівельний Університет, м. Баку, Азербайджанська Республіка
}

\section{КОНЦЕПТУААЬНИЙ ПІАХІААО РЕГУАЮВАННЯ ІНВЕСТИЦІЙНОЇ ПОАІТИКИ БУАІВЕАЬНИХ КОМПАНІЙ}

The article is devoted to the analysis analyzes the factors affecting the management of the investment policy of construction companies, measures taken to respond to external influences of companies in a competitive environment. Successful implementation of investment activities in construction companies requires the development of appropriate investment policies. This policy should be focused on the choice of methods and means of implementing priority areas of investment activity through the formation and using of investment resources in construction companies. Investment management is an integral part of investment policy and serves to increase in vestment attractiveness, evaluate and implement projects, create conditions for the effective progress of investment processes. The implementation of effective investment in construction companies requires the development of an optimal concept for managing the relevant investment policy. The mechanism for creating a favorable investment climate provides for the creation of a favorable investment climate. An integral part of the main economic policy are measures taken by the state to improve the efficiency of the investment climate.

If construction companies use strategic planning and strategic in vestment management, then a strategic direction should be added to them, to make corrections: to clarify and evaluate. To improve their investment performance construction companies should be aware that the rules, types and adoption of plans should be based on new approaches. In any system is an important issue maximizing the needs of society, people and staff. The needs of people are constantly growing, so it is necessary effectively use the available resources, including investment funds [4].

To determine the effectiveness of the economy implemented within the framework of the resource approach, it is necessary to divide the principles of using investment resources and improve the investment flows of construction companies.

During the research, methodological guidelines of leading scientific institutions dealing with the problem of improving the use of investment resources in construction companies. The research methodology used was the method of effective management of investment activity, resource method.

Статтю присвячено аналізу факторів, що вПливають на управління інвестиційною політикою будівельних компаній, заходів, що приймаються Аля реагування на зовнішні вПливи компаній в конкурентному середовищі. Успішне здійснення інвестиційної діяльності в будівельних компаніях вимагає розробки відповідної інвестиційної політики. Ця політика повинна бути орієнтованою на вибір методів і засобів реалізації пріоритетних напрямів інвестиційної діяльності через формування і використання інвестиційних ресурсів у будівельних компаніях. Управління інвестиціями є невід'ємною частиною інвестиційної політики і Служить ААя підвищення інвестиційної привабливості, оцінки та реалізації проєктів, створення Умов дАя ефективного розвитку інвестиційних процесів. Здійснення ефективних інвестицій в будівельні компанії вимагає розробки оптимальної концепції управління відповідною інвестиційною політикою. Механізм створення сприятливого інвестиційного кАімату передбачає створення сприятливого 
інвестиційного кАімату. Невід 'ємною частиною основної економічної політики є заходи, що вживаються державою щодо підвищення ефективності інвестиційного кдімату.

Якщо будівельні компанії використовують стратегічне планування і стратегічне управління інвестиціями, то до них САіА додати стратегічний напрям, щоб внести корективи: Уточнити і оцінити. Щоб поліпшити свої інвестиційні показники, будівельні компанії повинні усвідомлювати, що правила, типи і Плани повинні грунтуватися на нових підходах. Убудь-якій Системі важАивим є питання максимального задоволення потреб суспільства, людей і персоналу. Потреби Аюдей постійно зростають, тому необхідно ефективно використовувати наявні ресурси, в тому числі інвестиційні фонди.

Аля визначення ефективності економіки, яка реалізується в рамках ресурсного підходу, необхідно розділити принципи використання інвестиційних ресурсів і поліпшити інвестиційні потоки будівельних компаній.

Уході,досліАження розроблено методичні вказівки Аля провідних наукових УСтанов, що займаютьСя проблемою підвищення ефективності використання інвестиційних ресурсів у будівельних компаніях. У методології дослідження використовувалися методи ефективного управління інвестиційною діяльністю, ресурсний метод.

Key words: construction companies, investment, investment policy, management, environmental factors, concept

Ключові слова: будівельні компанії, інвестичї, інвестичійна політика, менеджмент, фактори навколишнвого середовища, кониепиіл.

\section{INTRODUCTION}

According to the Statistical Committee of the Republic of Azerbaijan there were 1901 construction companies in the country in 2020 [9]. Competition between companies is inevitable. That is why construction companies must take a number of measures to gain an advantage. These may include: if the construction companies want to become a leader in the construction sector, it must constantly improve its investment activity in order to achieve competitive advantages; construction companies must constantly improve the efficiency of their investment activities in order to avoid bankruptcy in a competitive environment and ensure consistent improvement of the strategy and action plan for the formation and using of investment resources; the strategy of the construction company must be flexible, otherwise the effectiveness of investment activity may decrease; investment activity of a construction company should be focused on the long term. Strengths and weaknesses of the construction companies should be identified using new methods and a comprehensive analysis; construction companies should always seek and develop new methods of doing business in order to gain a competitive advantage. Only in this case may increase the efficiency of investment activity.

It is advisable to develop a concept for managing the investment policy of construction companies.

\section{PURPOSE OF THE ARTICLE}

The main purpose of the article is to analyze the advantages of measures for the formation and implementation of the investment policy management concept. Provide recommendations for improving the implementation of investment policy at companies.

\section{PRESENTATION OF THE MAIN RESEARCH MATERIAL}

The resource approach based on assessing the effectiveness and structure of the using of construction projects. According to the application of the resource approach in the field of construction, attracting investment resources to companies can be considered as a process involving several elements. Assessment of investment opportunities of construction companies include these elements: search and collection of investment information; effective organization of attracting human resources at construction companies; development of investment plans, projects and programs of construction companies. The formation and efficient use of investment resources by construction companies reflects uncertainty, such as changes in external environment. In connection with the foregoing, it is necessary to take into account the dependence of the use of investment resources on the behavior of external environmental elements.

In the process of forming the investment idea of the project in accordance with the concept of development of investment activity of a construction company. The investment objectives are: the volume and characteristics of the product; project implementation period and the amount of income received, the importance of the invested object and sources of financing. All aspects of the investment project of a construction company should be considered before deciding on its implementation during the life cycle. Determination of decisions is carried out at certain stages of the investment project of a construction company in accordance with the development concept.

When design a development concept and feasibility study for an investment project of a construction company an environmental impact assessment of the facilities under construction should be carried out. Its advantages and disadvantages should be identified in the evaluation of the project to regulate the investment flows of the construction company, accordance development concept [3].

This concept gives an overview of the strategic goals and priorities of investment policy and the main directions of their implementation. In modern conditions, the concept of effective investment policy management should include the following approaches:

1. Justification of the choice of investment resources and investment instruments;

2. Investment activities aimed at ensuring the interests of the investor by increasing his income;

3. Assessment of the investment attractiveness of the asset and determination of the amount and timing of investments.

It is necessary to study the competitiveness of construction companies in the formation of investment policies. Therefore, it is necessary to analyze the dynamics of investment activity of companies, prices, quality and nature of their products.

In accordance with the competitiveness of the external environment, the principles of organizing the investment activities of construction companies are changing and improving. Therefore, new ideas should be recommended regarding effective ways of investing in construction 


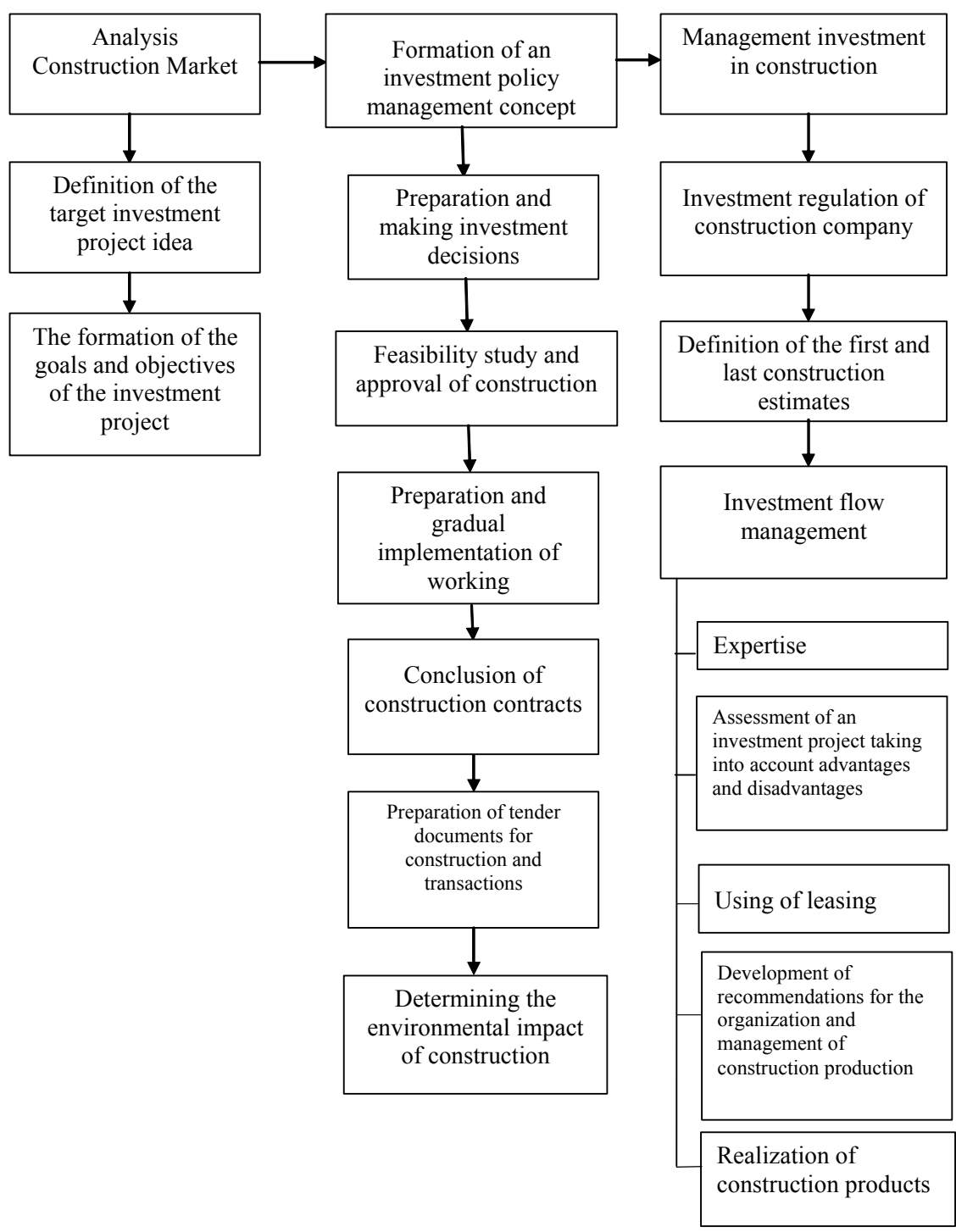

Fig. 1. Formation and implementation of the concept of management of the investment policy of a construction company

companies, as well as the creation and use of investment resources. Experience shows that: some construction companies the faster they have competitive advantages, the more often they lose. Because they do not develop a concept that would accurately reflect the structure of a favorable market and investment activity. For this reason, at present, is one of the most pressing issues increasing the investment activity of construction companies at the expense of using the resource approach. Should be developed special strategy of the company and introduced effective tactics, if company want to get the advantage of a competitive environment [8].

The strategy of the construction company should be aimed at strengthening its presence in the market and the corresponding action plan should be to maximize the profit, based on the performance of construction work. As a result, the strategic approach of the construction company is enhanced. At the same time, the behavior of a construction company changes depending on the elements of the external environment.

In a competitive environment construction company must respond quickly to competitor attacks. The construction company must know the essence and advantages of applying the resource approach to investment activity, must have an algorithm for its work and be able to use it. The development of investment policy management in construction companies can be used to regulate investment processes and the implementation of new reforms in this area will increase the efficiency of investment activities.
The main function of the investment policy management concept is to maintain the ability of construction companies to respond to internal and external changes and balance their investment resources [5]. The mechanism of regulation of investment flows of a construction company and the formation of investment resources is based on the implementation of the concept of investment policy management. The concept of managing investment policy and implementing a construction company can be schematically described as follows (Figure 1).

At the stage of developing the concept of investment policy of a construction company, the first examination of the investment project of the company should be carried out with a view to its implementation and a statement of intent should be drawn up. According to the concept, after developing an investment idea, the direction of the investment activity of the construction company is determined, that is, the formation of goals and objectives.

The main characteristics of the investment project are determined and include:

- technical solutions for an alternative investment project;

- determination of demand for project products;

- determination of the investment phase and duration of the project;

- calculation of the cost of production at current and forecast prices;

- determination of the complexity of the project and permits;

- investment climate in the project area;

- determination of the cost and proportions of the project.

As part of the formation of the concept, a preliminary analysis of the implementation of the investment project of the construction company is carried out. For this, the usual assessment is carried out through an expert system. The essence of the assessment is to analyze the investment project of a construction company in accordance with the development concept according to the relevant factors.

The content of the design information of the construction company, recommended for further consideration, and other requirements are determined. At the same time, a detailed marketing study of the investment project is carried out, engineering and geological surveys are carried out for the implementation of the project, the political situation in the country (region) and the socio-cultural conditions of the population are studied.

In accordance with the investment policy management concept, a declaration of intent is drawn up for the construction company (as an investor) and the investment is justified on the basis of pre-project information. These documents are prepared by project management consultants together with the investor (customer).

According to the concept, the effectiveness of an investment project of a construction company is assessed on the basis of generally accepted indicators (net profit, rate of return, internal rate of return).

A mechanism for the formation and use of tools and rules, forms and methods, investment resources for effective management of investment activities of construction companies is being organized. With the help of this mechanism, the work of construction companies is ensured, the behavior of goals, directions and rules for the formation 
of investment resources, an increase in the volume of investment resources to correspond to real opportunities is changed and refined. The mechanism for the formation of investment resources of construction companies include:

- identification of changes in the influence of elements of the external environment on the investment activities of construction companies;

- accounting of investment management mechanisms of construction companies in accordance with the elements of the external environment;

- determination of methods for the formation and use of investment resources in accordance with the forms and methods of investment activities of construction companies;

- creation of a unified mechanism for managing the investment activities of construction companies based on changes in the behavior of elements of the external environment.

The reaction of companies to changes in the elements of the investment environment of construction companies should be based on the concept of investment policy management and should be ensured:

- the reaction of companies to a simultaneous change in the elements of the external environment;

- react to management rules and legislation;

- responding to a delayed response of management.

There may be different reactions to construction incidents and hazards. These include the adaptation of construction facilities that are subject to change under the influence of external environmental elements, as well as the construction company's response to changes in investment resources and the external environment. The construction company must determine in advance the rate of change of events, taking into account changes in the external environment during the management of investment activities.

During the implementation of the investment policy management concept, the main functions of investment management of construction companies include identification of structural units of companies against weak signals and joint consideration of information trends and behavior of information about the external environmental elements of management, as well as characteristics of investment management environment of construction companies. It is necessary to study the problems that characterize the weak signals, to diagnose the causes and factors.

\section{CONCLUSIONS}

As a result of the research, ensuring the effective results of the activities of construction companies in the Republic of Azerbaijan is significantly related to the consistent improvement of the management of the investment process. Improving the overall efficiency of the construction sector requires strengthening the strategic directions of investment resource management. In this regard, the development of the concept of investment policy management in construction companies can play an important role. A construction company may be vulnerable to environmental changes when it comes to investment management, so the rate of change in events must be determined in advance.

The main function of the investment policy management concept is to maintain the ability of construction companies to respond to internal and external changes in investment management and the balance of their investment resources. In this regard, the mechanism for regulating investment flows and the formation of investment resources of a construction company is based on the implementation of the concept of investment policy management.

The analysis of factors affecting the effectiveness of the use of investment resources in construction companies was conducted on the basis of materials of the State Statistics Committee of the Republic of Azerbaijan, information and reports of construction companies.
References:

1. Abdullayev, T.P. (2009), Management of construction investment projects, Baku, Azerbaijan.

2. Aliev, A.B. and Mehdiyev, I.A. (2013), Analysis and investment management, Baku, Azerbaijan.

3. Alizada, S.I. (2018), "Development of the investment potential of construction companies in modern conditions", Economy and state, vol. 1, pp. 107-110.

4. Atakishiev, M.S. Nuralieva, R.N. and Abbasova, N.K. (2012), Organization of investment activity, Baku, Azerbaijan.

5.Dong, C. (2010), "Risk analysis of investment project", International Conference on E-Business and E-Government Guangzhou, China, 7-9 May. DOI: 10.1109/ ICEE.2010.1379

6. Farzaliyev, S. (2015), Construction management, textbook, Baku, Azerbaijan.

7. Maslennikov, V.V. Antonov, V.G. Skamay, L.G. and Vachegin, A.M. (2020), Risk management of priority investment projects. Concept and methodology: monograph., Moscow, Russia.

8. Yusifov, E.M. (2013), Analysis and development prospects of construction companies in Azerbaijan, Baku, Azerbaijan.

9. The State Statistical Committee of the Republic of Azerbaijan (2021), "Construction", available at: https:/ www.stat.gov.az/source/construction (Accessed 30 Sept 2021).

Стаття надійшла до редакиї 11.10.2021 p.

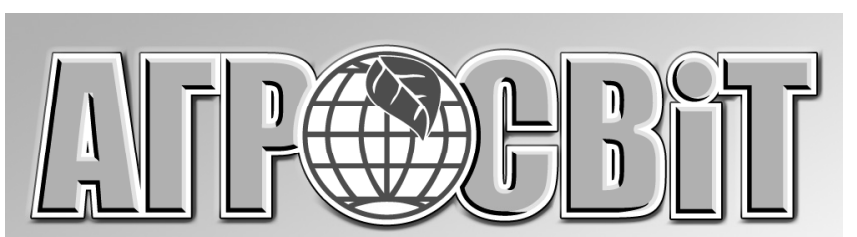

www. agrosvit. info

Передплатний індекс: 23847

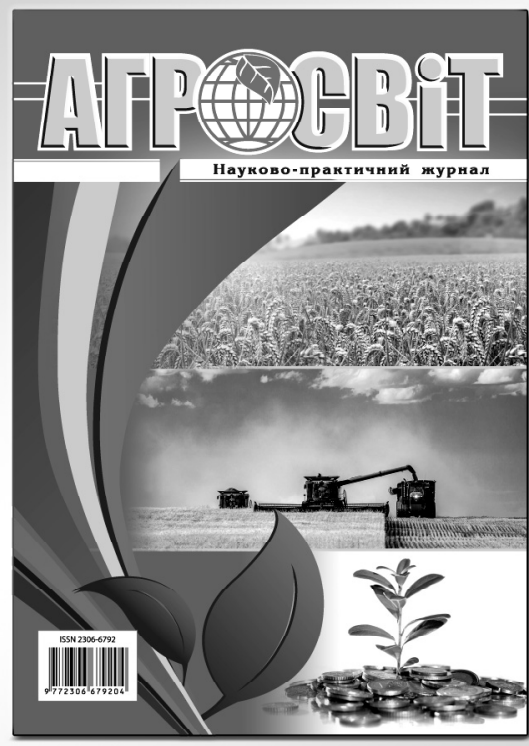

Виходить 24 рази на рік

\section{Журнал включено до переліку наукових фахових видань України 3 ЕКОНОМІЧНИХ НАУК (Категорія «Б»)}

Спеціальності - 051, 071, 072, 073, 075, 076, 292 